Prepared in cooperation with the Millennium Challenge Corporation

\title{
Groundwater Resources of Mosteiros Basin, Island of Fogo, Cape Verde, West Africa
}

\section{Overview of Cape Verde baseline groundwater study}

\section{Why was the study done?}

Groundwater resources in Cape Verde provide water for agriculture, industry, and human consumption. These resources are limited and susceptible to contamination. Additional groundwater resources are needed for continued agricultural development, particularly during times of drought, but increased use and (or) climatic change may have adverse effects on the quantity and quality of freshwater available. In volcanic island aquifers such as those of Cape Verde, a lens of fresh groundwater typically "floats" upon a layer of brackish water at the freshwater/saltwater boundary, and increased pumping may cause salt water intrusion or other contamination. A recent U.S. Geological Survey study (Heilweil and others, 2006, 2009) assessed baseline groundwater conditions in watersheds on three islands of Cape Verde to provide the scientific basis for sustainably developing water resources and minimizing future groundwater depletion and contamination.

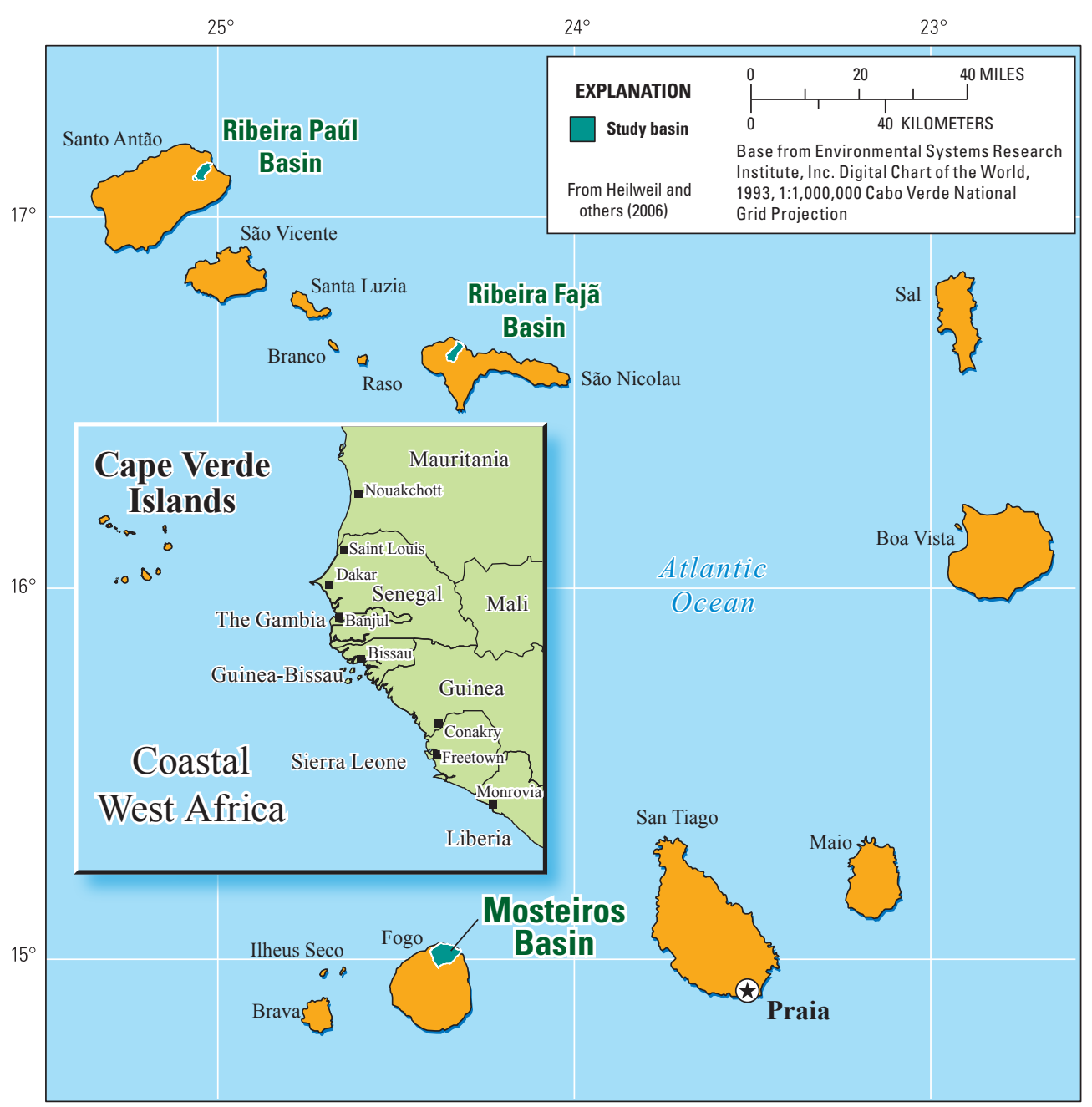

Figure 1. Location of study basins within Cape Verde, West Africa.

\section{Setting and approach}

Cape Verde is an archipelago of nine inhabited islands located about 750 kilometers off the west coast of Africa (fig. 1). Three watersheds were studied for the baseline groundwater study: Mosteiros Basin on Fogo (this fact sheet), Ribeira Fajã Basin on São Nicolau (Heilweil and others, 2010a), and Ribeira Paul Basin on Santo Antão (Heilweil and others, 2010b). Rainfall in Cape Verde varies greatly from year to year and with elevation. Average annual rainfall ranges from less than 50 millimeters along the populated coastal areas up to 1,000 millimeters in the highlands. Most of the population resides in rural areas and derives its livelihood from rain-fed agriculture; the irregular rainfall makes farming extremely challenging in all but the wettest areas (Haagsma, 1995).

Very few streams are perennial because most rainfall rapidly runs to the ocean, evaporates, or is used by plants, with the remainder infiltrating through permeable rock to recharge the underlying aquifers. The groundwater moves downgradient from the upper elevations to the lower parts of each watershed, where it discharges to wells, springs, streams, tunnels, and to the ocean as submarine discharge (fig. 2). To assess groundwater resources in each basin, data were collected at many of these discharge points. The resulting groundwater levels, flow measurements, and water chemistry analyses were used to assess groundwater budgets, recharge sources, travel times, vulnerability to contamination, and sustainability of pumping. 


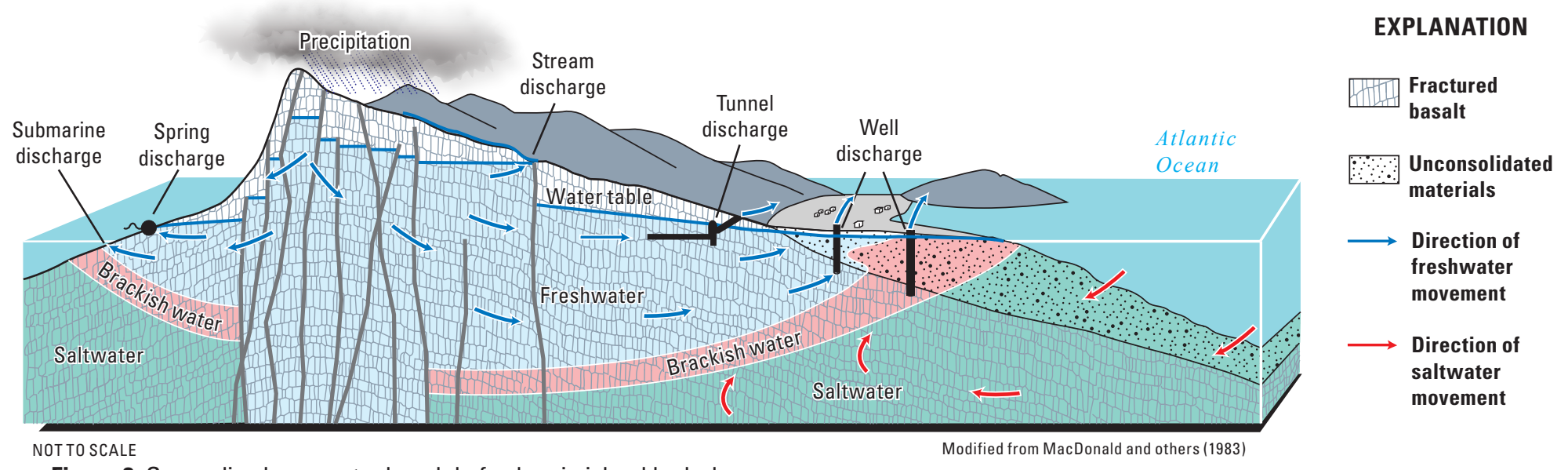

Figure 2. Generalized conceptual model of volcanic island hydrology.

\section{Mosteiros Basin, Fogo}

\section{Results - What was learned?}

Situated along the flank of the Fogo volcano (the highest point in the Atlantic Ocean at 2,900 meters), Mosteiros is the highest and largest of the three study basins. The average altitude in Mosteiros Basin is 820 meters, and it has an area of 42 square kilometers. The aquifer beneath Mosteiros Basin receives recharge from infiltration of part of the 600 millimeters of estimated average annual rainfall. The basin also likely receives recharge as subsurface inflow from the upgradient Cha das Caldeiras, a volcanic caldera with no surface-water outlet. Total measured discharge from wells and one spring during 2004-2005 was about 600 cubic meters per day, representing only 1 percent of the estimated rainfall in the basin. There is evidence that additional submarine discharge occurs off the coast of Mosteiros Basin, but this could not be measured. Most measured groundwater discharge is from Monte Vermelho Spring (fig. 3), which discharges about 500 cubic meters per day. Water levels in several wells

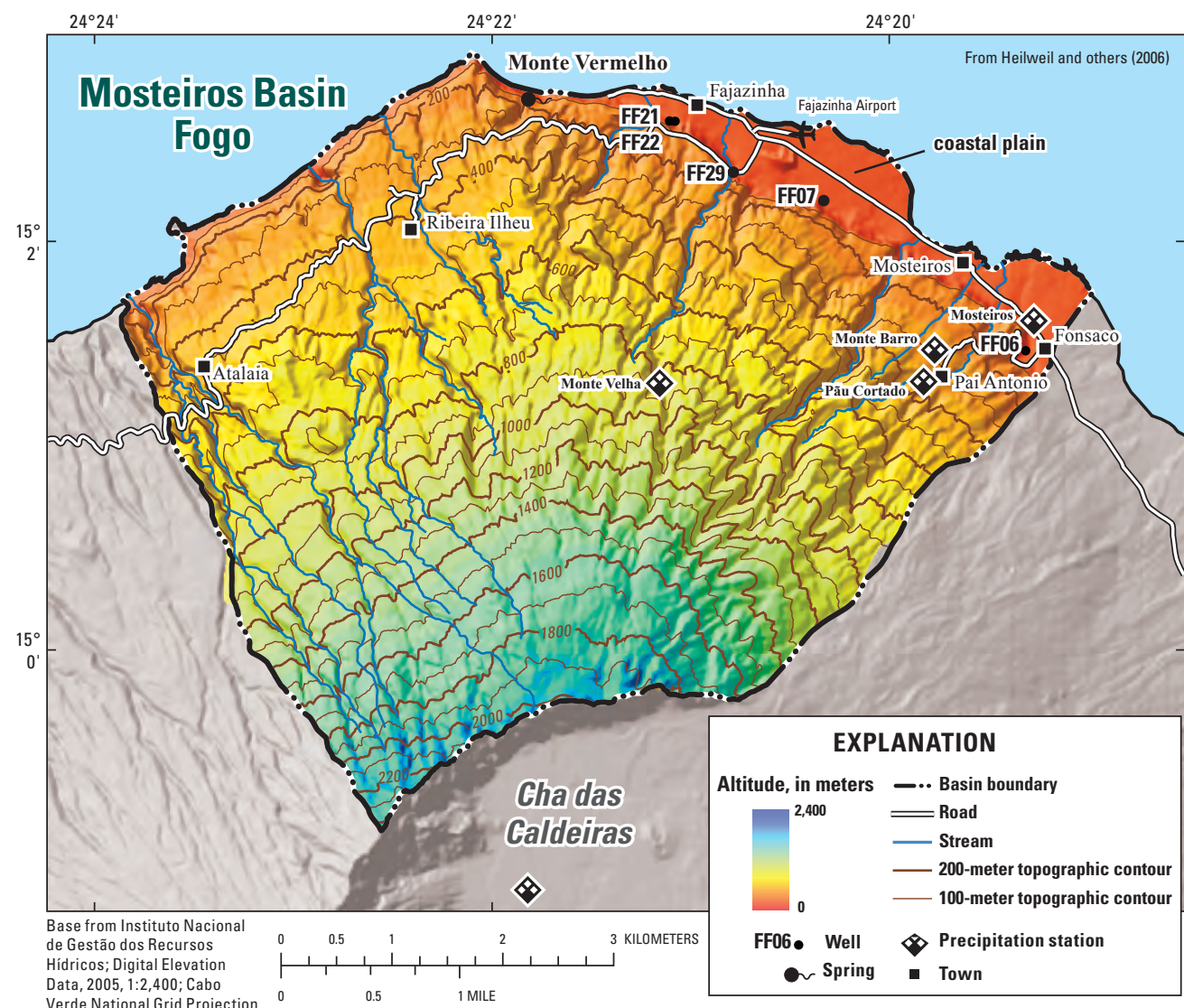
indicated that the top of the freshwater lens (water table) beneath the coastal plain is only a few meters above sea level. The water table is likely much deeper in the upper reaches of the basin, but could not be measured because of a lack of observation wells.

The quality of shallow groundwater in Mosteiros Basin is generally good. Salinity measurements in wells, however, indicated that there is only a thin lens of freshwater beneath the coastal plain, underlain by brackish groundwater. Therefore, the aquifer is vulnerable to saltwater intrusion from pumping, which removes freshwater and allows underlying and adjacent brackish water to move toward the pumped well. In addition, some nitrate is present in the groundwater, which implies that the aquifer is susceptible to contamination from agricultural fertilizer or septic waste. Environmental tracers used for dating

groundwater ${ }^{1}$ indicated a mixture of modern (1980s or younger) and older (pre-1950s) recharge, consistent with relatively low natural recharge rates and limited groundwater resources on this island. Other tracers indicated that much of the groundwater recharge to Mosteiros Basin enters the aquifer at high altitudes ${ }^{2}$ in the upper part of the watershed or perhaps through the adjacent Cha das Caldeiras.

${ }^{1}$ Environmental tracers used to determine age were tritium $\left({ }^{3} \mathrm{H}\right)$, tritiogenic helium $\left({ }^{3} \mathrm{He}_{\text {trit }}\right)$, chlorofluorocarbons $(\mathrm{CFCs})$, sulfur hexafluoride $\left(\mathrm{SF}_{6}\right)$, and carbon-14. Groundwater dating using the tritium/helium method was hampered by high concentrations of helium associated with volcanism or gases derived from the mantle. Similarly, several samples collected for $\mathrm{SF}_{6}$ analysis contained excess $\mathrm{SF}_{6}$ derived from volcanic rock and could not be dated.

${ }^{2}$ Based on depleted stable-isotope concentrations and cool groundwater recharge temperatures derived from dissolved-gas concentrations of neon, argon, krypton, and xenon. 


\section{Challenges for future water-resources development and management in Mosteiros Basin}

- Groundwater resources in Mosteiros Basin are limited in comparison to other watersheds in Cape Verde that have higher precipitation and infiltration.

- Existing production wells in the Coastal plain are near the ocean, and thus the aquifer is susceptible to overpumping and saltwater intrusion. Although the quality of groundwater in the basin is generally good, high salinity (exceeding the World Health Organization standard) has been measured during periods of high extraction, causing local water managers to reduce pumping.

- Capturing additional discharge from Monte Vermelho Spring may have less adverse impact than additional production wells.

- The majority of the population of Mosteiros lives on the narrow Coastal plain, where the underlying aquifer is shallow and susceptible to groundwater contamination from surface sources, such as agriculture, industry, and septic waste.

- Because of the water-quality and water-quantity concerns in Mosteiros Basin, careful stewardship and management practices will be essential for protecting water resources for future generations.

\section{By frequently monitoring Monte Vermelho spring- flow, rainfall, well pumping, water-level changes, and groundwater chemistry (salinity, nitrates), scientifically based metrics can be established to ensure sustainable future groundwater and agricultural devel- opment in Mosteiros Basin.}

By Victor M. Heilweil, Stephen B. Gingerich, L. Niel Plummer, and Ingrid M. Verstraeten

\section{What is saltwater intrusion?}

-When water is withdrawn from a freshwater lens, the freshwater lens shrinks and saltwater or brackish water will intrude upward and landward into parts of the aquifer that formerly contained freshwater. The degree of saltwater intrusion depends on several factors: the hydraulic properties of the rocks, recharge rate, pumping rate, and well location.

- Once saltwater intrudes into an aquifer, pumped water may be unsuitable for consumption or irrigation. The pumped water may have to undergo expensive treatment before use. Otherwise, pumping rates will have to be decreased and (or) other expensive engineering solutions must be used until the freshwater lens recovers over time. It is important, therefore, to protect susceptible aquifers from intrusion rather than to try to remediate groundwater resources once intrusion has occurred.

- Saltwater-intrusion problems can be minimized by appropriately locating wells and by controlling withdrawal rates.
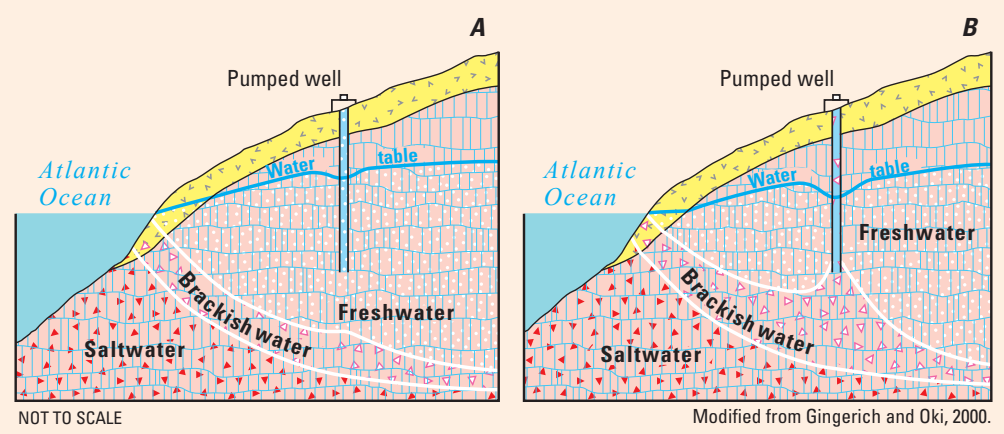

Saltwater intrusion is a potential problem near the coast. A, Diagram of a well completed in a volcanic-rock aquifer in which withdrawal is small. Only limited saltwater intrusion has taken place. B, Diagram of the same well under conditions of large ground-water withdrawal. Pumping has lowered the water table and caused the freshwater lens to thin. Brackish water has reached the well.

\section{Acknowledgements}

The USGS thanks the Millennium Challenge Account - Cape Verde, the Instituto Nacional de Gestão dos Recursos Hídricos, and local water management agencies in Mosteiros, Ribeira Paúl and Ribeira Fajã, for providing historical information and assistance with hydrologic data collection and interpretation.

\section{Additional resources}

Gingerich, S.B., and Oki, D.S., 2000, Groundwater in Hawaii: U.S. Geological Survey Fact Sheet 126-00, 6 p.

Haagsma, B., 1995, Traditional water management and state intervention: The case of Santo Antão, Cape Verde: Mountain Research and Development, v. 15, no. 1, p. 39-56.

Heilweil, V.M., Earle, J.D., Cederberg, J.R., Messer, M.M., Jorgensen, B.E., Verstraeten, I.M., Moura, M.A., Querido, A., Spencer, F., and Osorio, T., 2006, Evaluation of baseline ground-water conditions in the Mosteiros, Ribeira Paúl, and Ribeira Fajã Basins, Republic of Cape Verde, West Africa, 2005-06: U.S. Geological Survey Scientific Investigations Report 2006-5207, 42 p.

Heilweil, V.M., Gingerich, S.B., Plummer, L.N., Verstraeten, I.M., 2010a, Groundwater resources of Ribeira Fajã Basin, Island of São Nicolau, Cape Verde, West Africa: U.S. Geological Survey Fact Sheet 2010-3071, 6 p.

Heilweil, V.M., Gingerich, S.B., Plummer, L.N., Verstraeten, I.M., 2010b, Groundwater resources of Ribeira Paúl Basin, Island of Santo Antão, Cape Verde, West Africa: U.S. Geological Survey Fact Sheet 2010-3070, 6 p.

Heilweil, V.M., Solomon, D.K., Gingerich, S.B., and Verstraeten, I.M., 2009, Oxygen, hydrogen, and helium isotopes for investigating groundwater systems of the Cape Verde Islands, West Africa: Hydrogeology Journal, v. 17 , no. $5,1157-1174$

Langworthy, M. and Finan, T.J., 1997, Waiting for rain: Agriculture and ecological imbalance in Cape Verde: Boulder, Colorado, Lynne Rienner Publishers, ISBN 1-55587-709-5, 212 p.

MacDonald, G.A., Abbott, A.T., and Peterson, F.L., 1983, Volcanoes in the sea: The geology of Hawaii (2nd ed.): Honolulu, Hawaii, University of Hawaii Press, 517 p.
For more information, contact:

International Water Resources Branch

U.S. Geological Survey

12201 Sunrise Valley Drive

Reston, Virginia 20192

703-648-5230

This publication is available online at: http://pubs.usgs.gov/fs/2010/3069

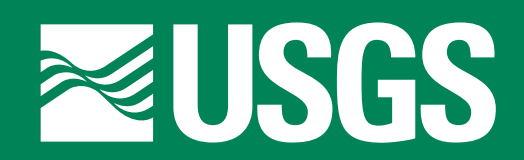

